\title{
Pengembangan E-Module Pemrograman Dasar Berbasis Masalah dalam Menunjang Pembelajaran di Masa Pandemi Covid-19
}

\author{
Nurmayanti ${ }^{1}$, Handy Ferdiansyah ${ }^{2}$, Zulkifli $\mathbf{N}^{3}$ \\ ${ }^{1}$ Teknologi Pendidikan/Universitas Muhammadiyah Sidenreng Rappang \\ ${ }^{2-3}$ Bisnis Digital/Universitas Muhammadiyah Sidenreng Rappang \\ * Corresponding Authors. E-mail: ${ }^{1}$ mayantii57@gmail.com \\ 2handyferdiansyah888@gmail.com \\ 3zulkiflin73@gmail.com
}

Receive: $12 / 02 / 2020$

Accepted: 28/02/2021

Published: 01/03/2021

\begin{abstract}
Abstrak
Penelitian ini bertujuan untuk (1) mengembangkan e-module pembelajaran pemrograman dasar berbasis masalah, (2) mendeskripsikan kelayakan dan kepraktisane-module pembelajaran pemrograman dasar berbasis masalah untuk menunjang pembelajaran SMK di masa pandemi Covid19. Desain penelitian ini menggunakan desain penelitian dan pengembangan model ADDIE yang terdiri dari lima tahapan, yaitu: (1) Analisis (Analyze), (2) Desain (Design), (3) Pengembangan (Development), (4) Implementasi (Implementation), dan (5) Evaluasi (Evaluation). Analisis data pada penelitian ini adalah analisis data deskriptif kualitatif dan kuantitatif. Hasil penelitian menunjukkan bahwa produk e-module yang dikembangkan memenuhi kriteria kevalidan dengan nilai persentase 90\%. Hasil uji lapangan menunjukkan bahwa e-module yang dihasilkan juga memenuhi kriteria kepraktisan dengan nilai persentase 92\%. E-Module Pemrograman Dasar Berbasis Masalah yang dikembangkan pada penelitian ini layak digunakan pada pembelajaran pemrograman dasar di SMK karena telah memenuhi kriteria kevalidan dan kepraktisan.
\end{abstract}

Kata Kunci: E-Module, Pemrograman Dasar, Berbasis Masalah, Pembelajaran, Covid-19.

\begin{abstract}
This study aims to (1) develop problem-based basic programming e-module learning, (2) describe the feasibility and practicality of problem-based basic programming e-module learning to support vocational learning during the Covid-19 pandemic. This research design uses the ADDIE model research and development design which consists of five stages, namely: (1) Analysis (Analyze), (2) Design, (3) Development, (4) Implementation, and (5) Evaluation. The data analysis in this research is descriptive qualitative and quantitative data analysis. The results showed that the e-module product developed met the validity criteria with a percentage value of $90 \%$. Field test results show that the emodule produced also meets the criteria for practicality with a percentage value of $92 \%$. The Problem-Based Basic Programming E-Module developed in this study is suitable for use in basic programming learning at SMK because it meets the criteria of validity and practicality.

Keywords: E-Module, Basic Programming, Problem Based, Covid-19.
\end{abstract}




\section{Pendahuluan}

Pendidikan kejuruan dalam hal ini SMK diarahkan untuk menghasilkan lulusan yang profesional, berdaya saing global, dan relevan dengan kebutuhan dunia usaha/dunia industri (DU/DI)(Wheelahan \& Moodie, 2017). Hal ini sejalan dengan Rencana Strategi (RENSTRA) Kemendikbud tahun 2020-2024 yang berfokus pada pembangunan Sumber Daya Manusia (SDM). Salah satu sasaran yang ingin dicapai berkaitan dengan penguatan mutu dan relevansi pendidikan berpusat pada perkembangan peserta didik adalah meningkatnya kualitas pembelajaran dan relevansi pendidikan yang dimuat di Permendikbud No. 22 tahun 2020. Lulusan SMK diharapkan menjadi tenaga profesional dan mampu bersaing di dunia kerja.

$$
\text { Sejak merebaknya wabah }
$$

Coronavirus Disease (Covid-19) di Indonesia,pemerintah mengambil langkah pencegahan penyebaran virus tersebut. Di bidang pendidikan, langkah pencegahan yang ditempuh yakni pelaksanaan proses belajar dari rumah (BDR) seperti tertuang pada Surat Edaran Nomor 4 tahun 2020. Pembelajaran harus dilaksanakan dengan meminimalisir kontak langsung antara peserta didik dengan peserta didik lain, juga antara peserta didik dengan guru(Firman \& Rahayu, 2020). Penggunaan teknologi digital menjadi solusi konkret agar proses pembelajaran tetap berlangsung meskipun guru dan peserta didik tidak berada di lokasi yang sama(Jones \& Healing, 2010).

Proses pembelajaran SMK tidak terlepas dari kegiatan praktikum yang menuntut peserta didik tidak hanya menguasai teori saja, namun juga keterampilan mengolah alat dan bahan praktikum sesuai dengan Standar Operasional Prosedur (SOP). Untuk mewujudkan hal tersebut, diperlukan sebuah panduan pembelajaran praktikum dalam bentuk modul pembelajaran. Modul sebagai sarana belajar mandiri, sehingga peserta didik dapat belajar secara mandiri sesuai kecepatan masing-masing. Hal ini sebagai wujud perubahan motode pengajaran dari teacher center learning menjadi student center learning pada kurikulum 2013, dimana peserta didik diharapkan lebih aktif dan kreatif dalam belajar mandiri(Rahmi \& Samsudi, 2020).

Modul adalah bahan ajar terprogram yang disusun sedemikian rupa dan disajikan secara sistematis, terpadu, serta terperinci (Daryanto \& Dwicahyono, 2014). Modul pembelajaran praktikum pada masa pandemi Covid-19 didesain dalam bentuk elektronik (E-Module) sehingga memudahkan peserta didik dalam mengaksesnya. Pembuatan modul elektronik ini diharapkan dapat menjadi pegangan bagi peserta didik sekaligus sebagai panduan dalam pelaksanaan praktikum dari jarak jauh. Dengan adanya modul elektronik ini juga diharapkan dapat meningkatkan hasil belajar peserta didik. $\mathrm{Hal}$ ini sejalan dengan hasil penelitian yang dilakukan(Cahyono, 2016), (Tsany \& Haryudo, 2015)yang menunjukkan bahwa pembelajaran dengan menggunakan modul efektif meningkatkan hasil belajar peserta didik.

Mata pelajaran di SMK yang menuntut terlaksananya praktikum yakni pemrograman dasar. Pemrograman Dasar adalah salah satu mata pelajaran wajib paket keahlian Teknik Komputer dan Jaringan yang harus dicapai oleh peserta didik SMK(Agustina et al., 2015). Materi pemrograman dasar berisi bahasa pemrograman yang diwujudkan dalam bentuk kode program yang sifatnya case sensitive(Ouahbi et al., 2015). Peserta didik dituntut lebih fokus dalam menyelesaikan susunan kode program.

E-moduleyang dikembangkan berupa modul elektronik yang berbasis masalah. Peserta didik dihadapkan pada suatu 
permasalahan untuk selanjutnya dicari solusinya. Proses inilah yang menjadi pembelajaran oleh peserta didik, dimana materi yang dipaparkan dalam $e$ modulemelatih peserta didik untuk berpikir kritis dalam menyelesaikan suatu permasalahan.

\section{Metode}

Penelitian ini merupakan penelitian dan pengembangan (Research and Development / R\&D) yang bertujuan untuk mengembangkane-modulepemrograman dasar berbasis masalah untuk menunjang pelaksanaan praktikum pada masa pandemi Covid-19.Model penelitian yang digunakan adalah model ADDIE (AnalyzeDesign-Development-ImplementationEvaluation).

Subjek penelitian ini adalah peserta didik Program Keahlian Teknik Komputer dan Jaringan (TKJ) SMK Negeri 1 Sidrap, SMK Negeri 2 Sidrap, dan SMK Negeri 5 Sidrap yang aktif mengikuti pembelajaran onlineserta guru mata pelajaran Pemrograman Dasar dari beberapa sekolah SMK di Kabupaten Sidrap. Teknik pengambilan sampel penelitian dilakukan dengan menggunakan teknik Random Sampling, dengan jumlah peserta didik sebanyak 30 orang dan guru sebanyak 6 orang. Penelitian dilakukan dengan menggunakan angket responden yang diberikan kepada guru dan peserta didik untuk mengetahuian kepraktisan penggunaan e-module dalam proses pelaksanaan praktikum di masa panndemi Covid-19.Analisis data yang digunakan pada penelitian ini adalah analisis deskriptif kualitatif dan kuantitatif. Analisis kualitatif untuk menganalisis data validasi ahli dan penngguna. sedangkan analisis kuantitatif digunakan untuk menganalisis data dari angket responden. Analisis kuantitatif yang dilakukan yaitu analisis kevalidan dan kepraktisan e-module berbasis masalah.
Rumus yang digunakan untuk mengetahui skor angket yakni:

$$
\text { Persentase }=\frac{\sum x}{\text { SMI }} \times 100 \%
$$

Keterangan: $\sum x=$ Jumlah skor, $\mathrm{SMI}=$ Skor Maksimal Ideal (Sumber:Tegeh et al., 2014)

Untuk mendapatkan kesimpulan tingkat kevalidan produk hasil pengembangan, maka melihat kriteria kevalidan pada Tabel 1.

Tabel 1. Kriteria Validitas

\begin{tabular}{cl}
\hline Kriteria Validitas & \multicolumn{1}{c}{ Kategori } \\
\hline $85,01 \%-100,00 \%$ & $\begin{array}{l}\text { Sangat valid, atau } \\
\text { dapat digunakan } \\
\text { tanpa revisi } \\
\text { Cukup valid, atau dapat } \\
\text { digunakan namun perlu } \\
\text { direvisi kecil }\end{array}$ \\
$50,01 \%-85,00 \%$ & $\begin{array}{l}\text { Kurang valid, atau dapat } \\
\text { digunakan namun perlu } \\
\text { direvisi besar } \\
\text { Tidak valid, atau tidak } \\
\text { boleh dipergunakan }\end{array}$ \\
\hline
\end{tabular}

Sumber: (Akbar, 2013)

Untuk mendapatkan kesimpulan tingkat kepraktisan penggunaan produk hasil pengembangan pada uji lapangan, maka melihat kriteria kepraktisan pada Tabel 2.

Tabel 2 Kriteria Kepraktisan

\begin{tabular}{cc}
\hline Kriteria Kepraktisan & Kategori \\
\hline $85,01 \%-100,00 \%$ & Sangat praktis \\
$70,01 \%-85,00 \%$ & Cukup praktis \\
$50,01 \%-70,00 \%$ & Kurang praktis \\
$01,00 \%-50,00 \%$ & Tidak praktis \\
\hline
\end{tabular}

Sumber: (Akbar, 2013)

\section{Hasil dan Pembahasan}

E-Module berbasis masalah berupa modul berbasis elektronik pada mata 
Jurnal Edumaspul, 5 (1), Year 2021- 25

(Nurmayanti, Handy Ferdiansyah, Zulkifli N)

pelajaran Pemrograman Dasar untuk membantu proses pembelajaran praktikum di masa pandemi Covid-19. E-module yang dihasilkan dikemas dengan adanya masalah yang menjadi inti dari pembelajaran. Masalah yang disajikan mendorong peserta didik untuk berpikir kritis mencari solusinya. Di dalam e-module juga disajikan materi yang merupakan kunci dari penyelesaian masalah yang ada. Contoh masalah yang disajikan dalam e-module dilihat pada Gambar 1.

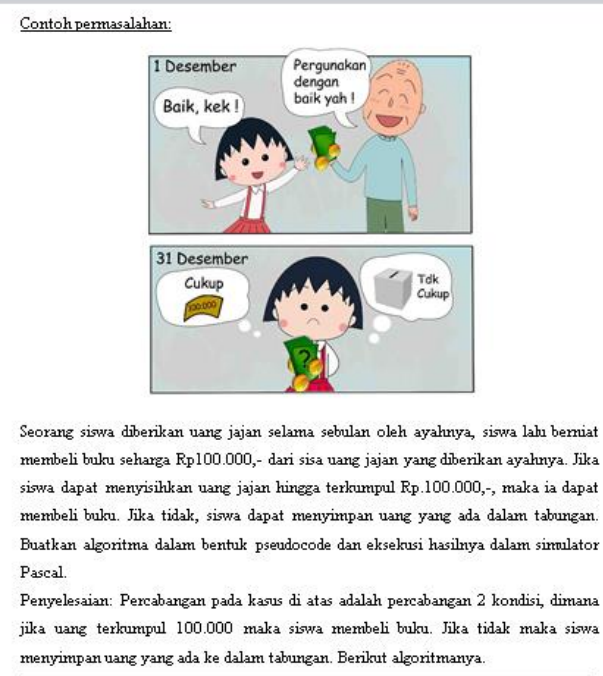

Gambar 1. Contoh Masalah dalam Emodule Berbasis Masalah

E-module berbasis masalah juga menyediakan latihan sebagai bahan evaluasi sekaligus sebagai penguatan materi praktikum. Penyajian latihan dalam e-module ditampilkan pada Gambar 2.

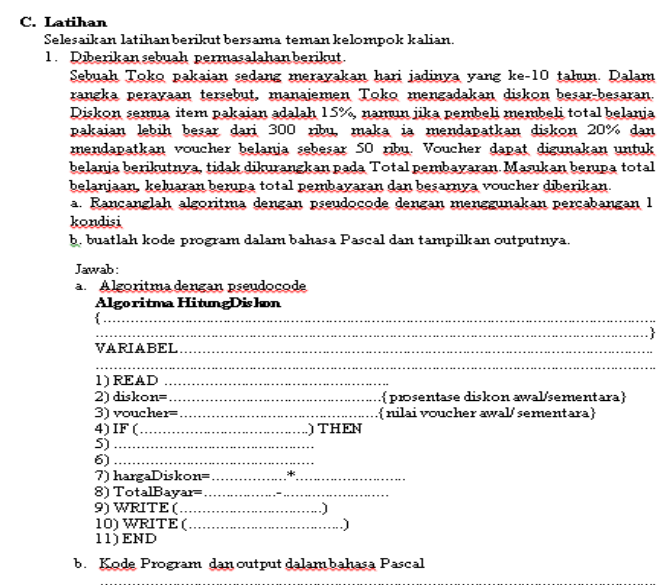

Gambar 2. Contoh Latihan pada EModule Berbasis Masalah

Prosedur penelitian pengembangan E-Module Pemrograman Dasar Berbasis Masalah menggunakan model pengembangan ADDIE (Analyze-DesignDevelopment-Implementation-Evaluation). Berikut langkah pengembangan ADDIE yang digunakan.

\section{Analisis (Analyze)}

Tahap analisis yang dilakukan yakni analisis kebutuhan berdasarkan hasil observasi awal di beberapa sekolah SMK di Kabupaten Sidrap. Masalah yang ditemukan meliputi: (1) pelaksanaan pembelajaran pemrograman dasar secara daring sehingga menghambat pelaksanaan praktikum, (2) belum adanya panduan pembelajaran praktikum secara elektronik sebagai pegangan peserta didik, (3) guru membutuhkan inovasi dalam menunjang pelaksanaan praktikum di masa pandemi Covid-19. Berdasarkan masalah yang ditemukan, peneliti mengidentifikasi kebutuhan akan e-module pembelajaran yang diharapkan menjadi penunjang pembelajaran praktikum secara daring. Penyajian materi e-module harusnya disesuaikan dengan karakter peserta didik agar sifatnya tidak monoton dan mudah dipahami.

\section{Desain (Design)}

Kegiatan yang dilakukan pada tahapan desain yakni merancang e-module pemrograman dasar berbasis masalah. Proses perancangan meliputi desain strategi pembelajaran praktikum yang cocok dengan situasi pandemi Covid-19, desain materi ajar berbasis masalah, desain tahapan praktikum, desain bentuk dan model evaluasi pembelajaran, serta desain tampilan e-module agar menarik minat 
peserta didik. Masalah yang dimunculkan dalam e-module dirancang dengan menyesuaikan karakter dan minat peserta didik yang cenderung menyukai gambar kartun dan game, sehingga mudah dicerna dan menarik minat dalam proses pembelajaran.

\section{Pengembangan (Development)}

Pada tahap pengembangan, peneliti mengimplementasikan desain yang telah direncanakan menjadi suatu bentuk nyata yakni e-module pembelajaran pemrograman dasar berbasis masalah yang menunjang pelaksanaan praktikum di masa pandemi Covid-19. Proses yang dilakukan di tahap pengembangan yakni mengumpulkan materi ajar dan referensi tambahan sesuai kompetensi dan tujuan pembelajaran, membuat gambar ilustrasi menggunakan Adobe Photoshop CS6, penyajian materi berupa kode program menggunakan simulator Pascal, pengetikan, pengaturan layout dan tampilan modul, serta penyusunan instrumen evaluasi pembelajaran.

\section{Implementasi (Implementation)}

Tahap implementasi dilakukan untuk mengetahui pengaruh penggunaan hasil pengembangan e-module pemrograman dasar berbasis masalah dalam proses pembelajaran praktikum di masa pandemi Covid-19. Namun, sebelum diimplementasikan dalam proses pembelajaran, hasil pengembangan $e$ module terlebih dahulu dilakukan uji validitas untuk mengetahui tingkat kelayakannya. Hasil uji validitas oleh ahli direvisi untuk menyempurnakan produk yang dikembangkan sebelum diujicobakan kepada peserta didik dalam proses pembelajaran. a. Uji Validasi Konten E-Module berbasis masalah

Aspek konten e-module yang dievaluasi oleh dua orang ahli di bidangnya yakni terdiri dari tiga indikator yang terbagi atas beberapa poin untuk mengukur kelayakan materi yang disajikan. Ketiga indikator tersebut adalah kejelasan, substansi materi, dan bahasa yang digunakan. Kesimpulan hasil penilaian validator terhadap konten e-module dilihat pada Tabel 3.

Tabel 3 Hasil Penilaian Konten EModul Berbasis Masalah

\begin{tabular}{ccccc}
\hline No & Indikator & Rerata & Presentase & Kesimpulan \\
\hline 1 & Kejelasan & 3,58 & $89,00 \%$ & Sangat Valid \\
2 & $\begin{array}{l}\text { Substansi } \\
\text { Materi }\end{array}$ & 3,59 & $90,00 \%$ & Sangat Valid \\
2 & Bahasa & 3,62 & $91,00 \%$ & Sangat Valid \\
\hline & $\begin{array}{c}\text { Rerata } \\
\text { indikator }\end{array}$ & 3,59 & $90,00 \%$ & Sangat Valid \\
\hline
\end{tabular}

Berdasarkan data pada tabel 3, dapat dilihat bahwa hasil penilaian validator terhadap konten e-module yang dikembangkan melihat dari beberapa indikator, mendapatkan nilai rerata 3,59 dengan persentase 90\% atau dikategorikan sangat valid. Produk yang dinilai dinyatakan layak untuk diujicoba lapangan dengan sedikit revisi. Saran yang diberikan validator untuk kesempurnaan konten e-modulepemrograman dasar berbasis masalah yakni (1) masih perlu menyesuaikan isi materi dengan RPP/Silabus dan (2) penulisan bahasa asing dicetak miring.

b. Uji Validasi MediaE-Module berbasis masalah

Aspek media pada e-module yang dievaluasi oleh dua orang ahli di bidangnya yakni mengarah kepada tampilan e-module, terdiri dari tiga 
Jurnal Edumaspul, 5 (1), Year 2021- 27

(Nurmayanti, Handy Ferdiansyah, Zulkifli N)

indikator yang terbagi atas beberapa poin. Ketiga indikator tersebut adalah kelayakan kegrafikan, komunikasi visual dan kepraktisan. Kesimpulan hasil penilaian validator tampilan $e$ module dilihat pada Tabel 4.

Tabel 4 Hasil Penilaian TampilanE-Modul Berbasis Masalah

\begin{tabular}{|c|c|c|c|c|}
\hline No & Indikator & Rerata & Presentase & Kesimpulan \\
\hline 1 & $\begin{array}{l}\text { Kelayakan } \\
\text { Kegrafikan }\end{array}$ & 3,58 & $89,00 \%$ & $\begin{array}{l}\text { Sangat } \\
\text { Valid }\end{array}$ \\
\hline 2 & $\begin{array}{l}\text { Komunikasi } \\
\text { Visual }\end{array}$ & 3,57 & $89,00 \%$ & $\begin{array}{l}\text { Sangat } \\
\text { Valid }\end{array}$ \\
\hline 2 & Kepraktisan & 3,65 & $92,00 \%$ & $\begin{array}{c}\text { Sangat } \\
\text { Valid }\end{array}$ \\
\hline & $\begin{array}{l}\text { Rerata } \\
\text { indikator }\end{array}$ & 3,60 & $90,00 \%$ & $\begin{array}{c}\text { Sangat } \\
\text { Valid }\end{array}$ \\
\hline
\end{tabular}

Berdasarkan data pada tabel 4 dapat dilihat bahwa hasil penilaian validator media terhadap tampilan $e$ module yang dikembangkan melihat dari beberapa indikator, mendapatkan rerata 3,60 dengan persentase $90 \%$ atau dikategorikan sangat valid. Produk yang dinilai dinyatakan layak untuk diujicoba lapangan dengan sedikit revisi. Saran yang diberikan validator untuk kesempurnaan tampilan e-module pemrograman dasar berbasis masalah yakni (1) perlu perbaikan penulisan, tata letak dan layout sampul, (2) perlu adanya variasi warna sampul yang menarik.

Hasil dari analisis kevalidan yakni gabungan antara data hasil uji validasi konten dan tampilan $e$ module. Analisis kevalidan $e$ module pemrograman dasar berbasis masalah secara keseluruhan mendapatkan nilai rerata 3,59 dengan persentase 90\%. Berdasarkan kriteria kevalidan maka produk yang dihasilkan termasuk dalam kriteria "sangat valid".

c. Kepraktisan PenggunaanE-Module berbasis masalah

Data aspek kepraktisan terhadap e-module didapatkan dari angket responden yang dibagikan secara daring melalui google form. Angket responden dibagikan kepada subjek penelitian, yakni peserta didik dan guru mata pelajaran pemrograman dasar dari tiga sekolah SMK di Kabupaten Sidenreng Rappang yang melaksanakan pembelajaran daring.

\section{Hasil Penilaian Responden Peserta Didik}

Angket responden dibagikan kepada peserta didik dari SMK Negeri 1 Sidrap, SMK Negeri 2 Sidrap dan SMK Negeri 5 Sidrap. Angket respon peserta didik terdiri dari dua indikator, yakni kemudahan dan manfaat yang terbagi atas beberapa butir penilaian. Data hasil analisis angket respon peserta didik dapat dilihat pada Tabel 5.

Tabel 5 Hasil Analisis Angket Respon Peserta Didik

\begin{tabular}{ccccc}
\hline No & Indikator & Rerata & Presentase & Kesimpulan \\
\hline 1 & $\begin{array}{c}\text { Kemudahan } \\
\text { Menggunakan } \\
\text { Modul }\end{array}$ & 3,69 & $92,00 \%$ & $\begin{array}{l}\text { Sangat } \\
\text { Praktis }\end{array}$ \\
\hline & Manfaat & 3,70 & $92,00 \%$ & $\begin{array}{l}\text { Sangat } \\
\text { Praktis }\end{array}$ \\
\hline & Rerata & 3,69 & $92,00 \%$ & $\begin{array}{l}\text { Sangat } \\
\text { Praktis }\end{array}$ \\
\hline
\end{tabular}

Berdasarkan hasil analisis angket respon peserta didik terhadap produk e-module pada tabel 5, didapatkan nilai rerata 3,69 dengan persentase 92\% dari dua indikator penilaian. Dapat disimpulkan bahwa e-module pemrograman dasar berbasis masalah dikategorikan sangat praktis. 
2. Hasil Penilaian Responden Guru Mata Pelajaran

Angket responden dibagikan kepada guru mata pelajaran pemrograman dasar dari SMK Negeri 1 Sidrap, SMK Negeri 2 Sidrap dan SMK Negeri 5 Sidrap.Angket respon duru mata pelajaran terdiri dari empat indikator, yakni bahasa, materi, latihan dan pelaksanaan pembelajaran yang terbagi atas beberapa butir penilaian. Data hasil analisis angket respon guru mata pelajaran dapat dilihat pada Tabel 6 .

Tabel 6 Hasil Analisis Angket Respon Guru Mata Pelajaran

\begin{tabular}{ccccc}
\hline No & Indikator & Rerata & Presentase & Kesimpulan \\
\hline 1 & Bahasa & 3,67 & $92,00 \%$ & $\begin{array}{l}\text { Sangat } \\
\text { Praktis }\end{array}$ \\
2 & Materi & 3,65 & $91,00 \%$ & $\begin{array}{l}\text { Sangat } \\
\text { Praktis }\end{array}$ \\
3 & Latihan & 3,70 & $92,00 \%$ & $\begin{array}{l}\text { Sangat } \\
\text { Praktis } \\
4\end{array}$ \\
\hline $\begin{array}{c}\text { Pelaksanaan } \\
\text { Pembelajaran }\end{array}$ & 3.66 & $92,00 \%$ & $\begin{array}{l}\text { Sangat } \\
\text { Praktis }\end{array}$ \\
\hline & $\begin{array}{c}\text { Rerata } \\
\text { Indikator }\end{array}$ & 3,67 & $92,00 \%$ & $\begin{array}{l}\text { Sangat } \\
\text { Praktis }\end{array}$ \\
\hline
\end{tabular}

Berdasarkan hasil analisis angket respon guru mata pelajaran terhadap produk e-module pada tabel 6, didapatkan nilai rerata 3,69 dengan persentase $92 \%$ dari empat indikator penilaian. Dapat disimpulkan bahwa e-module pemrograman dasar berbasis masalah dikategorikan sangat praktis.

Hasil dari analisis kepraktisan yakni gabungan antara data hasil analisis respon peserta didik dan guru mata pelajaran terhadap penggunaane-module pada uji lapangan. Analisis kepraktisanemodule pemrograman dasar berbasis masalah secara keseluruhan

\begin{abstract}
mendapatkan nilai rerata 3,68 dengan persentase $92 \%$. Berdasarkan hasil analisis maka disimpulkan bahwa penggunaan $e$ module pemrograman dasar berbasis masalah yang termasuk dalam kriteria "sangat praktis" digunakan dalam proses pembelajaran praktikum di SMK Negeri 1 Sidrap, SMK Negeri 2 Sidrap dan SMK Negeri 5 Sidrap.
\end{abstract}

\section{Evaluasi (Evaluation)}

Tahap evaluasi pada pengembangan e-module pemrograman dasar berbasis masalah dilakukan melalui evaluasi formatif dan evaluasi sumatif. Evaluasi formatif dilakukan pada setiap tahapan model pengembangan, sedangkan evaluasi sumatif dilakukan setelah e-module diterapkan pada proses pembelajaran untuk mengetahui pengaruh penggunaan e-module terhadap kualitas pembelajaran maupun pada hasil belajar peserta didik dari segi pengetahuan dan keterampilan.

\section{Kesimpulan}

E-Module Pemrograman Dasar Berbasis Masalah dikembangkan menggunakan model pengembangan ADDIE (Analyze, Design, Development, Implementation, Evaluation). E-module yang dikembangkan pada penelitian ini layak digunakan pada pembelajaran pemrograman dasar, dibuktikan pada hasil analisis kevalidan dan kepraktisan. Hasil analisis kevalidan dari aspek konten dan tampilan e-module mendapatkan nilai $90 \%$, sedangkan hasil analisis kepraktisan berdasarkan angket respon peserta didik dan guru mata pelajaran mendapatkan nilai $92 \%$. Hal ini menunjukkan bahwa $e$ module yang dikembangkan sangat valid sesuai dengan kriteria kevalidan dan sangat praktis digunakan dalam proses 
Jurnal Edumaspul, 5 (1), Year 2021- 29

(Nurmayanti, Handy Ferdiansyah, Zulkifli N)

pembelajaran praktikum pada mata pelajaran pemograman dasar.

\section{Daftar Pustaka}

[1] Agustina, N. K. D., Damayanthi, L. P. E., Sunarya, I. M. G., \& Putrama, I. M. (2015). Pengembangan E-Modul Berbasis Metode Pembelajaran Problem Based Learning pada Mata Pelajaran Pemrograman Dasar Kelas $X$ Multimedia di SMK Negeri 3 Singaraja. 4, 8.

[2] Akbar, S. (2013). Instrumen Perangkat Pembelajaran. PT Remaja Rosdakarya.

[3] Cahyono, B. (2016). Korelasi Pemecahan Masalah dan Indikator Berfikir Kritis. Phenomenon: Jurnal Pendidikan MIPA, 5(1), 15-24. https://doi.org/10.21580/phen.2015. 5.1.87

[4] Daryanto, D., \& Dwicahyono, A. (2014). Pengembangan Perangkat Pembelajaran (Silabus, RPP, PHB, Bahan Ajar) (1st ed.). Gava Media.

[5] Firman, F., \& Rahayu, S. (2020). Pembelajaran Online di Tengah Pandemi Covid-19. Indonesian Journal of Educational Science (IJES), 2(2), $\quad$ 81-89. https://doi.org/10.31605/ijes.v2i2.65 9

[6] Jones, C., \& Healing, G. (2010). Networks and locations for student learning. Learning, Media and Technology, 35(4), 369-385. https://doi.org/10.1080/17439884.2 010.529914

[7] Ouahbi, I., Kaddari, F., Darhmaoui, H., Elachqar, A., \& Lahmine, S. (2015). Learning Basic Programming Concepts by Creating Games with Scratch Programming Environment. Procedia - Social and Behavioral Sciences, 191, 1479-1482.

https://doi.org/10.1016/j.sbspro.201 5.04.224

[8] Rahmi, M. N., \& Samsudi, M. A. (2020). Pemanfaatan Media Pembelajaran Berbasis Teknlologi Sesuai Dengan karakteristik Gaya Belajar. Edumaspul: Jurnal Pendidikan, 4(2), 9.

[9] Tegeh, I. M., Jampel, I. N., \& Pudjawan, K. (2014). Model penelitian pengembangan. Yogyakarta: Graha Ilmu.

[10] Tsany, A. A., \& Haryudo, S. I. (2015). Pengembangan Modul Pembelajaran Berbasis Masalah Pada Mata Pelajaran Dasar dan Pengukuran Listrik Untuk Meningkatkan Hasil Belajar Siswa di Kelas X TIPTL SMK Negeri 7 Surabaya. Jurnal Pendidikan Teknik Elektro, 04(02), 433-438.

[11] Wheelahan, L., \& Moodie, G. (2017). Vocational education qualifications' roles in pathways to work in liberal market economies. Journal of Vocational Education \& Training, 69(1), 10-27. https://doi.org/10.1080/13636820.2 016.1275031

\section{Profil Penulis}

Penulis pertama Nurmayanti, S.Pd., M.Pd., lahir di Rappang, 11 Desember 1994. Pendidikan sarjana ditempuh penulis di Universitas Negeri Makassar dengan mengambil Jurusan Pendidikan Teknik Elektro, Program Studi Pendidikan Teknik Informatika dan Komputer. Pada jenjang magister, penulis melanjutkan pendidikannya di Universitas Negeri Makassar pada Program Studi Pendidikan Teknologi dan Kejuruan, Kekhususan Pendidikan Teknik Informatika dan Komputer. Saat ini penulis tercatat sebagai dosen di Universitas Muhammadiyah Sidenreng Rappang, Program Studi Teknologi Pendidikan. 
Penulis kedua yaitu Handy Ferdiansyah, S.Pd., M.Pd. Penulis lahir di Rappang, 01 Januari 1988. Pendidikan sarjana ditempuh penulis di Sekolah Tinggi Keguruan dan Ilmu Muhammadiyah Rappang Program Studi Teknologi Pendidikan. Pada jenjang magister, penulis melanjutkan pendidikan di Universitas Negeri Makassar Program Studi Teknologi Pendidikan. Saat ini penulis tercatat sebagai dosen di Universitas Muhammadiyah Sidenreng Rappang, Program Studi Bisnis Digital.

Penulis ketiga yaitu Zulkifli N, S.Pd., M.Pd. Penulis lahir di Ciro-ciroe, 27 Juni 1993. Pendidikan sarjana ditempuh penulis di Sekolah Tinggi Keguruan dan IImu Muhammadiyah Rappang Program Studi Teknologi Pendidikan. Pada jenjang magister, penulis melanjutkan pendidikan di Universitas Negeri Makassar Program Studi Teknologi Pendidikan. Saat ini penulis tercatat sebagai dosen di Universitas Muhammadiyah Sidenreng Rappang, Program Studi Bisnis Digital. 